\title{
Alter
}

Revue de phénoménologie

$20 \mid 2012$

Eros

\section{Motivation and Person: the Ethical Life as a Stream of Consciousness}

Nicola Zippel

\section{(2) OpenEdition}

\section{Journals}

\section{Electronic version}

URL: http://journals.openedition.org/alter/1110

DOI: $10.4000 /$ alter. 1110

ISSN: 2558-7927

\section{Publisher:}

Association ALTER, Archives Husserl (CNRS-UMR 8547)

\section{Printed version}

Date of publication: 1 December 2012

Number of pages: $197-210$

ISBN: 978-2-95-223748-2

ISSN: 1249-8947

\section{Electronic reference}

Nicola Zippel, «Motivation and Person: the Ethical Life as a Stream of Consciousness », Alter [Online], 20 | 2012, Online since 01 July 2019, connection on 28 July 2019. URL : http://

journals.openedition.org/alter/1110; DOI : 10.4000/alter.1110

Revue Alter 


\title{
MOTIVATION AND PERSON: THE ETHICAL LIFE AS A STREAM OF CONSCIOUSNESS
}

\begin{abstract}
Nicola Zippel
Abstract: Starting from the separation between rational and irrational motivation, Husserl elaborates a formal ethics which justifies the universal validity of its principles on the logical feature of proposition. On the other hand, since the irrationality of motivation represents the associative stream of consciousness constituting the passive background of rational life of subject, the formal aspect of Husserlian ethics seems to be well rooted in the materiality and concreteness of existence. For this reason, it becomes hard to maintain the separation between the two kinds of motivation, and it is necessary to study in depth their intentional connection.
\end{abstract}

\section{Rational and Irrational Motivation}

In the Chapter VI of the Introduction to Ethics of 1920s, after critically dealing with the hedonist reading of the moral, Husserl interrupts the historical confrontation with the previous theories to introduce the basic theme of motivation using an authentically phenomenological description.

Such a description begins referring to the sensualistic and naturalistic psychology mentioned and criticised in the prior chapters, in order to stress its inborn limits that blinds it "to the peculiar sense which the question concerning the reason has and can only have, the question concerning the origin of spiritual matter of fact"1. The

\footnotetext{
${ }^{1}$ Edmund Husserl, Einleitung in die Ethik. Vorlesungen Sommersemester 1920/1924, Hua XXXVII, Hrsg. von H. Peucker, Dordrecht, Kluwer Academic Publishers, 2004, p. 104.
} 
reference to the sphere of the "reason" and of the "origin" not only points to the direction an ethical investigation must follow, but also gives a first, implicit connotation of the ethics itself. A little bit further ahead in the text Husserl indeed explains that "the peculiar essence of the entire spiritual sphere refers to the essence of the subjects of the whole spirituality as subjects of intentional lived experiences; these subjects are Egos, are personal subjects." 2 . To question the reason and the origin involves then paying attention to the intentional subjectivity as person, since the "whole" spiritual essence shows itself only in the personal shape of consciousness; hence, the analysis of such an essence can allow the complete elaboration of a philosophical ethics ${ }^{3}$.

To reach the origin of the spiritual life, namely the realm of motivation, means finding a very complex structure which is divided according to the basic difference between "rational" and "irrational" motivation. To the latter corresponds the territory of the "passive or affective, inferior" spirituality ${ }^{4}$. Here continuous sense-references take place generated within the stream of consciousness without a real control by the Ego; they occur through an unaware process of the spiritual life which is based on the association. Husserl gives the example of someone's name that, once pronounced, reawakens the memory of a trip occurred in the past with him. But the currently present thought doesn't concern the person or the trip; rather, it refers to the Engadin, namely the place visited with that person. Starting from this thought suddenly emerged to the current attention I go back over the elapsed stream of consciousness and finally find the associative link between the pronounced name, the trip to Engadin, and the current thought of Engadin. According to Husserl, this thought is the result of an irrational motivation, since though it is understandable as to its "reason", it is not the effect of an aware theoretical course by the subject; the subject did not decide to think about Engadin, but rather it happened to her to think about it.

On the contrary, if I state that Germany will rise again from the post-war depression thanks to the capacity of German people, this statement shows the traits of rational motivation; in the same way the answer to the question about the reason of our action or behaviour is rational if "one responds presenting the guide-goal"5. Husserl explains that in both cases the assertions are expressed by full

\footnotetext{
${ }^{2}$ Edmund Husserl, Einleitung in die Ethik, p. 104.

${ }^{3}$ See Ullrich Melle, «Husserl's personalist ethics», in Husserl Studies, no 1, 2007, pp. 1-15.

${ }^{4}$ Cf. Edmund Husserl, Einleitung in die Ethik, p. 107.

${ }^{5}$ Edmund Husserl, Einleitung in die Ethik, p. 107.
} 
awareness and as such they are able to exhibit a rational ground: they can not only justify the origin of their emerging, which is also possible in the case of the thought addressed to the Engadin, but they also can appeal to the legitimacy of their content, and account for what they express. Despite being intentionally motivated (one can explain its emergence going back over the intentional-constitutive stream), the thought of Engadin is not rationally legitimated: it doesn't account for reason. In this sense, it is out of an ethical explanation, and so it risks crossing the border of being understandable. It is the case of the entrance in the consciousness' life of an unexpected sensible datum, such as a sudden bang: "The bang produces itself and flows through the consciousness, but it has, in a strict sense, no «genesis». Nevertheless, if I recognize it as a signal announcing a counter-signal, then the entrance of the latter in the consciousness has its genesis" 6 . But also in this case the motivation is irrational, because it doesn't need to justify the right to expect a counter-signal, although such an expectation is entirely understanddable with regard to its intentional genesis.

Husserl doesn't further deal with such "inferior" level and describes it as "that of pure passivity which denotes the trait of the psychic, of what is ego-less (ichlos), namely of the substrate flowing without an active participation by the Ego [...]. In the lower sphere of consciousness, in the sub-egological one (unter-ichlich), geneses flow, motivational binds interweave, but in a entirely passive way; here the Ego doesn't act, doesn't unify anything; here everything occurs by itself'7. And yet one has to add: everything occurring in that sphere constitutes the passive root of the active life and as such it has repercussions on the aware surface belonging to the properly subjective dimension, like in the example of the Engadin. To what extent do such repercussions intervene in the field of the ethical decisions? To what extent the "superior" level of the motivational rationality is conditioned by the "inferior" level, the one of the associative irrationality? On the basis of Husserl's statements there seems to be no determining interaction between the two levels, considering that to the irrational motivations as such "one can't clearly put any question of reason" 8 ; and, on the other hand, the motivations emerging within the sphere of egological act "are motivations of reason, which

\footnotetext{
${ }^{6}$ Edmund Husserl, Einleitung in die Ethik, p. 109, emphasis mine.

${ }^{7}$ Edmund Husserl, Einleitung in die Ethik, p. 110.

${ }^{8}$ Edmund Husserl, Einleitung in die Ethik, p. 111.
} 
means that these motivations submit to the questions regarding the rationality and the irrationality, the legitimacy and the illegitimacy"9.

From this point on Husserl leaves the correlation between passive and active motivation and focuses only on the latter, which represents the original source of a possible ethical life. This ethical sphere is described through a continuous parallelism with the logical sphere. Such a parallelism (that Husserl had already presented in Chapter I of the book) is based on the consideration that the logic sets out its truths apart from the relation with the unaware, irrational, passive dimension of consciousness' life. Nevertheless, if this is valid for the logic, is it equally valid for the ethics which is so structurally tied to the living dimension of subject as person that it is very hard to separate rationality and irrationality?

For now we follow the course of argument by Husserl, who describes in detail the rational motivation and its multiple senseconnections directly or indirectly referring to the centrality of the egological, subjective decision. Also in the case of a sort of "mechanicczation" of the ethical choices, i.e. when the moral virtues are applied according to an apparently independent habit, this mechanization "has to be preceded by an active ethical decision. A habitual spur to do the "good" to others that doesn't stem from the application of authentic acts of love for the neighbour is a blind, irrational instinct"10. In this way, Husserl refutes the claim of sensualist psychology to ground the altruism on an originary egoism which becomes a virtue thanks to a habitual mechanism lacking an aware choice by the Ego. Husserl affirms that if the choice fails, the responsibility fails too, and so the worth of the choice fails. If we do the good on the basis of a mechanic habit, our action is not suitable to be judged right or wrong, since it follows an inner necessity that as such can't be otherwise. But it is precisely this "to can be otherwise" that characterizes every ethical decision of the subject which in turn can be valuated as to its legitimacy or illegitimacy. On the contrary, if the ethical life is reduced to the pure natural sphere of the mechanic though motivated association, this life lacks "of the inner sense and of the corresponding inner rational valorisation which must be the motivational base of the tending to do something"11. A phenomenological analysis of the ethical behaviour can reveal this rational, aware root of motivation; since such analysis only is able to distinguish the two levels of

\footnotetext{
${ }_{9}^{9}$ Edmund Husserl, Einleitung in die Ethik, p. 112.

${ }^{10}$ Edmund Husserl, Einleitung in die Ethik, p. 116.

${ }^{11}$ Edmund Husserl, Einleitung in die Ethik, p. 116.
} 
motivation and to understand that every modification in the subjective attitude even though it occurs on a passive background, it is not reducible to this passivity, but it shapes a lucid and carefully considered life which became emancipated from the mere associative connection. This is a life able as such to justify itself and to which one can ask for justification.

\section{Rationality and Subjectivity}

The egological, subjective trait is crucial to understand the rationality connoting the life as an ethical one. Every Ego-act bestows sense to the means and the aims that are adopted by the ethical behaviour, which makes the rational motivation a privileged form of active intentionality; because it ignored the intentional mark of subjective life, the complex, yet comprehensible play of sense-references of this life, the sensualist psychology wasn't able to elaborate a genuine, authentic ethics, which develops through acts undergoing valuation and judgment. Paradoxically, the mechanization of ethical life thought by the sensualist psychology exempts this ethics from critiques, since one can't be considered responsible for actions that he/she doesn't master. Just like there is neither worth nor blame if one thinks of the Engadin. Nevertheless, such an exemption from the valuation is based not on an ethical perfection, rather on the absence of a real ethical connotation. Without praise or blame, the Ego of the sensualist psychology doesn't deal with ethics, and her judgements don't concern the logical dimension. On the contrary, the Ego of phenomenological ethics is continuously submitted to the valuation of her acts, and her logical judgments are always considered right or wrong; her ethical choices as well as her logical statements take place within the sphere of full rational awareness. Husserl explains that in this sphere it is possible to accomplish an original "appropriation", a solid "having" of a choice or of a judgment, and in this way one becomes responsible of her own actions and sentences.

Parallelism with the logic helps Husserl to refute as a whole the naturalist psychology that fails "in all of the problems of reason"12 logical as well as ethical, because in both the same subjective feature is involved, which is precisely the one misunderstood by psychology. Furthermore, this parallelism reinforces the conceptual capacity of phenomenological ethics, since the sense-bestowments determining

${ }^{12}$ Edmund Husserl, Einleitung in die Ethik, p. 116. 
the essence of judging and the comprehension of the logic act in parallel in the development of the ethics of the subject's life. Therefore Husserl points out that "one has investigated so in depth the sphere of judgment and the specific of judging reason in the ambit of judgemotivations, that one can expect to find in the other act-spheres and their peculiar act-motivations parallel eidetic situations"13. The constant reference to the logic means the criterion to confer to the ethical acts an analogous rationality in order to give the motivation a scientific mark as expression of ethical laws. Only if the ethical sentences possess an intrinsic legality they can demand to be valid for all in the same way of a logical principle. According to a phenomenological perspective, the eidetic character makes the law an all-encompassing, universal rule provided with that invariability which is valid each time and in each space. Such validity is a form of rationality and so it plays a basic role in the concreteness of subjectivity, which is determined by the motivation and constitutes the natural place for working out and respecting the ethical norms.

Precisely such constitutive passage through the egological features warrants the concrete, empirical effect of ideal validity on the daily, worldly existence; the proposition (Satz) as the elementary Ego's act expresses, grounds, and communicates a normative eidos: "as far as, idealiter, arrives in general the possibility that a proposition the Ego puts can be put by everyone, and through an ideally possible empathy it can be recognized as the same by everyone [...] then every foundation or removal of fundament is a priori a common good"14. The public, social level of subjective life allows to enlarge over the personal horizon an ethical conviction, since the approval by others is not only a confirmation of his/her own opinions, but it represents also an acknowledgment of the legitimacy of the expressed ideas ${ }^{15}$. In the case such opinions utter a rational motivation they have an eidetic legality as sense-correlate. Husserl states that the asserted proposition becomes a "common good" (Gemeingut), because it does not gain its argumentative power from the public agreement, but rather it is publicly agreed as expression of an eidos. It is "unthinkable" (i.e.

\footnotetext{
${ }^{13}$ Edmund Husserl, Einleitung in die Ethik, p. 116.

${ }^{14}$ Edmund Husserl, Einleitung in die Ethik, p. 121.

15 The social dimension of Husserlian ethics has been recently put in evidence through a comparison of Husserl's thought with Rawls' political philosophy. See Margaret Steele, «Husserl and Rawls: Two Attempts to Free Moral Imperatives from Their Empirical Origin», in Epistemology, Archaeology, Ethics. Current Investigations of Husserl's Corpus, Vandevelde, P., Luft, S. (Eds.), London \& New York, Continuum, p. 222.
} 
theoretically, logically inacceptable) that where a right appears, who recognizes it could deny its validity ${ }^{16}$.

As structures of a consciousness' subject who draws directly from the eidetic nucleus of a truth, logic and ethics are parallel forms expressing one and the same scientific rigorous source, to which modern philosophy could not aspire, because of its naturalistic tendency depending on the example of positive sciences. The theoretical trait of reason, along with its valuing activity by proposition, seems to throw off balance the parallelism towards a logical foundation of ethics, namely towards a building of a logical ethics. Only by this it is possible to oppose with efficacy the ethics to the sceptical objections that pick on the reason on the whole with regard both to the judgement and to the valuation. As it is a form of knowledge and grounds itself on the validity of principles first thought and subsequently applied, ethics bases its practical capacity on the conceptual solidness of its statements, which in turn must have a theoretical, logical strictness guaranteeing their right to be valid in a universal way. Such strictness is due to the eidetic, i.e. the legal hallmark that ethics not only shares but also derives from logic, of which it uses the propositional form. From the beginning of the lectures Husserl explicitly states that ethics "has the advantage of having the pattern of logic, and it is very relevant considering the inmost affinity that essentially exists between the ethical problematic and the logical one"17. Such affinity is already noticeable with regard to the common struggle against the naturalistic philosophy both as logical scepticism (psychologismus) and as ethical scepticism (hedonism, utilitarianism, aestheticism). When he recalls the medieval doctrines on the supra-empirical validity of ethical truths as regards the relation between God and such truths, Husserl evokes not by accident examples made in the Prolegomena to the Logical Investigations ${ }^{18}$, and clearly confirms the parallelism with the logic: "what is ethically good (like what is logically true) is good (or true) not because God requests it and arbitrarily has in this way established, rather God requests it, because it is good in itself, it is true in itself" ${ }^{\prime 1}$.

\footnotetext{
${ }^{16}$ Cf. Edmund Husserl, Einleitung in die Ethik, pp. 121-122.

${ }^{17}$ Edmund Husserl, Einleitung in die Ethik, p. 30.

18 See Edmund Husserl, Logische Untersuchungen. II Band. Erster Teil, Hua XIX/1, Hrsg. von U. Panzer, The Hague, M. Nijhoff Publishers, 1984, §36. Work that he plainly reminds in the $\S 3$ of the Introduction to the Ethics.

${ }^{19}$ Edmund Husserl, Einleitung in die Ethik, p. 130. In his previous lectures on ethics in Gottingen, Husserl elaborated in depth such correlation with the logic. See Edmund Husserl, Vorlesungen über Ethik und Wertlehre (1908-1914), Hua XXVII, Hrsg. von U. Melle, Dordrecht, Kluwer Academic Publishers, 1988. Henning Peucker observes that this reference to the logical dimension also
} 
Nevertheless, in the following pages Husserl himself warns about the risk inherent in this parallelism, if it assumes the shape instituted by Ralph Cudworth ${ }^{20}$ and Samuel Clarke ${ }^{21}$ between mathematical laws and ethical laws. The mathematical law possessing an intrinsic incontrovertibility is made by Cudworth and Clarke a synonymous of natural law that is impossible to violate; the ethical law provided with the "material" (sachlich) characters of the mathematical law could in turn not be violated, and that implies a de-responsibility of the Ego who remains the real subject in all of the senses of Husserlian ethics $^{22}$. Hence, the parallelism with the logic must not assume the form of an ethical rationalism, which makes the practical legalities other expressions of the physical nature that is on principle "extranormative and extra-valuative (außer-wertlich)" 23 .

The motivation phenomenologically considered as basic property of subjective life allows not reducing the ethics to a system of objective life without a reference to the intentional i.e. human dimension of existence ${ }^{24}$. This relation becomes visible if one shifts the attention from the eidetic sphere to the concrete praxis occurring in the spiritual life, "the life which is first of all infinitely rich and multiform, the life which one lives in first person, in which one is living and develops"25. As a philosophy of lived experience, phenomenology is the method that permits to reveal the deeper structures of an ethics of person. As it shifts "the regard backwards on the Ego and on the egological activity itself" 26 , phenomenology is able to grasp the constitutive trait of self-determination, which puts the eidetic legality in the personal life of subject. By adapting Shaftesbury's discourse on

\footnotetext{
in the reflections from 1920s testifies the persistence of a formal basis of phenomenological ethics. See Henning Peucker, «Einleitung des Herausgebers», in Edmund Husserl, Einleitung in die Ethik, p. XXIV. With regard to this parallelism logic/ethics as forms of reason see also Ullrich Melle, «Husserl's personalist ethics», p. 8.

${ }^{20}$ Ralph Cudworth [1731], A Treatise Concerning Eternal and Immutable Morality, New York, Garland, 1976.

${ }^{21}$ Clarke [1706], A Discourse Concerning the Unchangeable Obligations of Natural Religion, and the Truth and Certainty of the Christian Revelation, Stuttgart-Bad Cannstatt, Frommann, 1964.

${ }^{22}$ In the first "Kaizo" article, Husserl talks about a centering Ego-pole, in which the consciousness' acts stand in a connection of motivation. See Edmund Husserl Aufsätze und Vorträge (19221937), Hua XXVII, Hrsg. von T. Nenon und H.-R. Sepp, Dordrecht, Kluwer Academic Publishers, 1989 , p. 8.

${ }^{23}$ Edmund Husserl, Einleitung in die Ethik, p. 146.

24 See Marcus Brainard, "FFor a New World": On the practical impulse of Husserlian theory», in Husserl Studies, no 1, 2007, pp. 17-31.

${ }^{25}$ Edmund Husserl, Einleitung in die Ethik, p. 124.

${ }^{26}$ Edmund Husserl, Einleitung in die Ethik, p. 123.
} 
"reflection" 27, Husserl makes the reflection an act requested by an Ego who is motivated "to want herself as Ego who-wants-the-

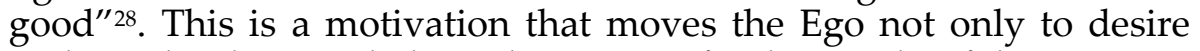
and to do the good, but also to verify that each of her actions corresponds to her purposes. Such a reflection doesn't take place only a posteriori with the task to sanction the pretended legitimacy of the accomplished act, but it has, besides the evaluative function, also the constitutive function and contributes together with the motivation to the constant renewal of the personal-ethical Ego's life ${ }^{29}$. Motivating herself to do the good, and contextually reflecting upon the validity and efficacy of her motivations, the Ego determines herself as a subject who consciously chooses the attitude to assume. The idea of us as moral persons involves recognizing both the continuity of the actions addressed to a goal and the personal responsibility for the coherence of the praxis. The moral Ego knows herself "not only as the one who lives and tends in a specific way, but also as the one led and determined by herself, as the one wanted and gained on the basis of a reflective self-valuation. The moral Ego knows herself as causa sui of her own morality" 30 .

\section{Passivity and Rationality}

This self-control, once it is firmly acquired by the Ego, assumes the habitual shapes of morality that goes on daily in an "unreflective" manner, according to "a unitarily teleological regulation, whose form is co-instituted in advance, but whose material content is determined subsequently through the unforeseeable course of «experience», in which the moral will confer a form to this course" 31 . Although it

\footnotetext{
${ }^{27}$ Shaftesbury, Anthony A. Cooper, Third Earl of [1711], Characteristics of Men, Manners, Opinions, Times, Cambridge, Cambridge University Press, 1999.

${ }_{28}$ Edmund Husserl, Einleitung in die Ethik, p. 162.

${ }^{29}$ As regards the topic of renewal, see Edmund Husserl, Aufsätze und Vorträge, p. 20 sqq.

${ }^{30}$ Edmund Husserl, Einleitung in die Ethik, p. 163. Tom Nenon plainly gets to the point of the connection between responsibility and evaluation in Husserlian ethics: "What makes us ethically responsible is not that we normally do subject all of our actions to explicit or even implicit scrutiny through second-order mental acts but rather that we see ourselves as always in principle capable of doing so if we choose to reflect on them as our own and capable of evaluating them in terms of the general norms for practical rationality", Tom Nenon, "Freedom, Responsibility, and Self-Awareness in Husserl», in Edmund Husserl. Critical Assessments of Leading Philosophers, R. Bernet, D. Welton, G. Zavota (Eds.), London \& New York, Routledge, 2005, p. 155.

${ }^{31}$ Edmund Husserl, Einleitung in die Ethik, p. 164. As John Drummond clearly explains: "Both the material and contextual dimensions of our evaluative judgements indicate that the absolute and universal character which belongs to the laws of formal axiology might not belong to the
} 
unfolds by now in an unreflective manner, the moral life remains anyway guided by the reflection which originally determines its daily path and makes this life a "second nature", in the sense that "the morality entirely belongs to the realm of spirituality and doesn't belong at all (gar nicht) to the realm of sub-spiritual (unter-geistig) passivity of the psyche or to the realm of psycho-physical nature" 32 .

One has to ask: can Husserl affirm with legitimacy that the morality doesn't belong "at all" to the passive sphere, to the dimension of pure egoless consciousness? The radical meaning of this assertion is not justified considering what Husserl himself said about motivation in the aforementioned pages. Although the separation between rational and irrational motivation is clearly put with regard to the lacking participation of the Ego to the reasonless, i.e. passive streaming of the pure consciousness' motivations, Husserl adds that in this sphere "we have no Ego's act, an act of truth-reckoning, of judging, of valuing, albeit such an act can refer to it [the stream] and albeit all of these acts can draw nourishment (Nahrung ziehen) from this consciousness' background"33. This passage doesn't allow to affirm the entire not-belonging of morality to the sub-spiritual, subegological life of the psyche. The formation of the Ego reaches its full development as a rational and practical person in the ethical life consciously self-determined, responding to the motivations that move the subject to establish norms of behaviour provided with an eidetic and so universally binding content. Nevertheless, such personal development has an undeletable root precisely in that egoless, pre-reflective sphere which gives nourishment to the rational subject $^{34}$.

concrete moral judgments we make. Those judgments have not only a formal dimension but a material one (both a priori and empirical), and the material dimension is relative to the context in which the concrete judgment is made", Drummond «Moral Objectivity. Husserl's Sentiments of the Understanding», in Edmund Husserl. Critical Assessments of Leading Philosophers, R. Bernet, D. Welton, G. Zavota (Eds.), London \& New York, Routledge, 2005, p. 84.

32 Edmund Husserl, Einleitung in die Ethik, p. 165.

${ }^{33}$ Edmund Husserl, Einleitung in die Ethik, p. 111.

${ }^{34}$ In the same years of the Ethic's Lectures, Husserl develops the centrality of motivation with regard to the inner life of subject and her relationship with the surrounding world. See Husserl 1966. See also the following proper remarks by Anthony Steinbock: "Relations of motivation permeate all dimensions of intentional life: broadly speaking, with the active sphere in terms of egoic motivations of interest; within the passive sphere, e.g. in terms of fusion or connection of matters within a sense-field, or again, in terms of kinaesthetic motivations; and in the transition from the passive to the active sphere [...].", Anthony Steinbock «Translator's Introduction», in Edmund Husserl, Analyses Concerning Passive and Active Synthesis, Dordrecht, Kluwer Academic Publishers, 2001, XLVII. 
The higher level of personality is the one in which an individual holds "the capacity to consciously let him/herself be guided in the selfformation by the norms of ethical duty"35; in that case, the propositional formulation of the principles of practical behaviour achieves the scientific strictness of logic, and therefore the "consciousness' background" doesn't exert any determining influence. But in the daily, habitual course of moral life in which the logical form of principles meets the unforeseeableness of experience, what happens in the sphere of irrationality, while not determining for the evaluation of an ethical choice, structurally contributes as passive intentionality for the realization of the active performances of subject. Precisely as "second" nature of a "first" i.e. primordial, primal nature, the moral life with regard to its habitual route and in the unreflective constituting stratifications belongs to the inferior sphere of consciousness' passivity ${ }^{36}$.

Once the normative form, which each act of ethical life must undergo, is established, the feature of reflection is constantly contaminated by the concrete contact with the experience, namely with the sensible elements of passive intentionality enabling such contact. The first element is precisely the irrational motivation as association.

Thus the ethical life assumes in a phenomenological perspective the shapes of a subjective ethics, an ethics of a person who sets up fully consciously her own basic principles according to eidetic legalities as universally normative; but as the ethics of a person provided also with an inborn passive structure determining her development just as rational individual, it is an ethics not entirely under subjective control. This does not concern the self-evaluation, which is founded on the rational nature of the decisional top of ethical praxis i.e. the $\mathrm{Ego}^{37}$, but it exactly refers to that passive "background" that the Ego has to use as a sensible filter necessary to achieve an ethical, concrete experience. It is precisely on the basis of this standpoint that Husserl criticizes the Kantian formalism blameworthy to be lacking the "consideration regarding the matter of will, the material contents

\footnotetext{
${ }^{35}$ Edmund Husserl, Einleitung in die Ethik, p. 9.

${ }^{36}$ In the Appendix VI of his Ethics, Husserl talks again of the relationship between rational, active motivation and irrational, passive motivation, and defines the latter as the humus (Mutterboden) of reason, which as such has the predisposition (Empfänglichkeit) to the authentically rational life of subject. What is produced in the active, aware reason it is already outlined (schon angelegt) on the field of passive motivation as "potential reason". See Edmund Husserl, Einleitung in die Ethik, p. 332.

${ }^{37}$ In the third "Kaizo" article, Husserl affirms that the "personal self-consideration (inspectio sui)" belongs to the essential skills of man. See Husserl 1989, 23. It is about what Drummond properly calls "the moral urgency at the heart of Husserl's philosophy: to decide for oneself", Drummond, 2005, 96.
} 
worth, so to speak, being desired, [consideration that] can show the way I must will in the concrete case; these material contents themselves have to provide me the basis of will, the reasons of will, to provide me and equally to each rational being" 38 .

Leaving out of consideration whether the critical remark moved by Husserl to Kant is legitimate or not ${ }^{39}$, it is worth stressing that such a remark needs to be properly maintained so that one doesn't totally separate the morality from the sphere of passivity; the acknowledgment of the being rooted in the materiality, in the impersonal concreteness of consciousness, allows to develop a person's ethics which doesn't reduce itself to mere formal statements, but it is able to give a philosophical guide to the individual praxis already inserted in the everyday "unforeseeable" experience. Nevertheless, to admit the contamination of lucid and rational intentionality of the ethical Ego by the spontaneous and irrational intentionality of the stream of consciousness $^{40}$ means that one has to consider to what extent the mixture of activity and passivity occurring in every concrete acts conditions, co-originates and even modifies the solidness of enunciation of ethical principles. If the irrationally motivated thought of Engadin has no influence on my moral behaviour, is it possible to affirm the same with regard to a potential thoughtless, unreflective reaction to an ethical norm? In that case one has a norm whose universal validity is known and theoretically established, and yet whose validity has been concretely violated. If the irrational motivation constitutes the nourishment of subjective praxis, and if this motivation as irrational is considered not-chargeable, does it mean a de-responsibility of personal action? This probing points to the classic question of free will of individual ${ }^{41}$.

\footnotetext{
${ }^{38}$ Edmund Husserl, Einleitung in die Ethik, p. 235.

${ }^{39}$ Critical remarks about Husserl's statements regarding Kant's imperative have been recently expressed by Rinofner-Kreidl. See Sonja Rinofner-Kreidl, «Husserl's Categorical Imnperative and His Related Critique of Kant», in Epistemology, Archaeology, Ethics. Current Investigations of Husserl's Corpus, Vandevelde, P., Luft, S. (Eds.), London \& New York, Continuum, 2010, pp. 188-210.

${ }^{40} \mathrm{In}$ his latest reflections on time-consciousness, Husserl distinguishes between an inauthentic intentionality belonging to the egoless sphere of passivity, and the authentic intentionality of Ego's active, aware performances. See Edmund Husserl, Späte Texte über Zeitkonstitution (1929-1934). Die C-Manuskripte, Hrsg. von D. Lohmar, «Husserliana Materialen VIII», Dordrecht, Springer, 2006, Ms. C 6, pp. 112-113. Within the ambit of the inquiry on ethics, such distinctions can be expressed by the following terminology: "There is intentionality in the sense onf consciousness-of and there is intentionality in the sense of striving, tendency", Ullrich Melle, "Husserl's Phenomenology of Willing», in Edmund Husserl. Critical Assessments of Leading Philosophers, R. Bernet, D. Welton, G. Zavota (Eds.), London \& New York, Routledge, 2005, p. 75.

${ }^{41}$ Husserl was well aware of the difficult to clearly define the autonomous realm of will, as one can infer from this passage contained in a manuscript quoted by Melle: "the general investigation of the possible structures of willing is in need of the difficult investigations of the
} 
On the other hand, if the sub-egological, pre-reflective sphere of life is involved in the moral behaviour, the discourse about motivation needs to be rethought starting not from the separation between irrational and rational motivation, i.e. between stream of consciousness and Ego, rather from a more careful consideration of their structural, congenital, and problematic interrelations ${ }^{42}$.

\section{References}

Brainard, M. (2007). "For a New World": On the practical impulse of Husserlian theory, "Husserl Studies", 1, pp. 17-31.

Clarke, S. [1706] (1964). A Discourse Concerning the Unchangeable Obligations of Natural Religion, and the Truth and Certainty of the Christian Revelation, Frommann: Stuttgart-Bad Cannstatt.

Cudworth, R. [1731] (1976). A Treatise Concerning Eternal and Immutable Morality, Garland: New York.

Drummond, J. (2005). Moral Objectivity. Husserl's Sentiments of the Understanding, in Edmund Husserl. Critical Assessments of Leading Philosophers, R. Bernet, D. Welton, G. Zavota (Eds.), Routledge: London \& New York, pp. 80-98.

Husserl, E. (1966). Analysen zur passiven Synthesis. Aus Vorlesungs- und Forschungsmanuskripten 1918-1926, Hua XI, Hrsg. von M. Fleischer, M. Nijhoff: The Hague.

Id. (1984). Logische Untersuchungen. II Band. Erster Teil, Hua XIX/1, Hrsg. von U. Panzer, M. Nijhoff Publishers: The Hague.

Id. (1988). Vorlesungen über Ethik und Wertlehre (1908-1914), Hua XXVII, Hrsg. von U. Melle, Kluwer Academic Publishers: Dordrecht.

Id. (1989). Aufsätze und Vorträge (1922-1937), Hua XXVII, Hrsg. von T. Nenon und H.-R. Sepp, Kluwer Academic Publishers: Dordrecht.

Id. (2004). Einleitung in die Ethik. Vorlesungen Sommersemester 1920/1924, Hua XXXVII, Hrsg. von H. Peucker, Kluwer Academic Publishers: Dordrecht.

general structures of consciousness, since the correct demarcation of the shapes of consciousness that the word 'will' is supposed to characterize is hardly an obvious matter", Ullrich Melle, «Husserl's Phenomenology of Willing», p. 76.

42 Unfortunately, Husserl seems to not follow such direction of inquiry in his famous "Kaizo" articles either, where he talks about a struggle of the ethics life with the "tendencies dragging down (herabziehenden Neigungen)" (see Edmund Husserl, Aufsätze und Vorträge, p. 43), according to a picture reminding the Plato's myth of winged team of horses and their charioteer (Phaedrus, 246a-247c), that doesn't help to overcome the dualistic structuring of the motivation's issue we criticize. 
Id. (2006). Späte Texte über Zeitkonstitution (1929-1934). Die C-Manuskripte, Hrsg. von D. Lohmar, «Husserliana Materialen VIII», Springer: Dordrecht.

Melle, U. (2005). Husserl's Phenomenology of Willing, in Edmund Husserl. Critical Assessments of Leading Philosophers, R. Bernet, D. Welton, G. Zavota (Eds.), Routledge: London \& New York, pp. 61-79.

Id. (2007). Husserl's personalist ethics, "Husserl Studies", 1, pp. 1-15.

Nenon, T. (2005). Freedom, Responsibility, and Self-Awareness in Husserl, in Edmund Husserl. Critical Assessments of Leading Philosophers, R. Bernet, D. Welton, G. Zavota (Eds.), Routledge: London \& New York, pp. 140-162.

Peucker, H. (2004). Einleitung des Herausgebers, in Husserl, E., Einleitung in die Ethik. Vorlesungen Sommersemester 1920/1924, Hua XXXVII, Kluwer Academic Publishers: Dordrecht, pp. XII-XLV.

Rinofner-Kreidl, S. (2010). Husserl's Categorical Imnperative and His Related Critique of Kant, in Epistemology, Archaeology, Ethics. Current Investigations of Husserl's Corpus, Vandevelde, P., Luft, S. (Eds.), Continuum: London \& New York, pp. 188-210.

Shaftesbury, Anthony A. Cooper, Third Earl of [1711] (1999). Characteristics of Men, Manners, Opinions, Times, Cambridge University Press: Cambridge.

Steele, M. (2010). Husserl and Rawls: Two Attempts to Free Moral Imperatives from Their Empirical Origin, in Epistemology, Archaeology, Ethics. Current Investigations of Husserl's Corpus, Vandevelde, P., Luft, S. (Eds.), Continuum: London \& New York, pp. 211-223.

Steinbock, A. (2001). Translator's Introduction, in Husserl, E. Analyses Concerning Passive and Active Synthesis, Kluwer Academic Publishers: Dordrecht, pp. XV-LXVII. 